\title{
食物アレルギーの発症における食用油クオリティの影響 油の質がアレルギー体質を決める！？
}

近年, 食と健康の重要性が一般的に広く認識されるよ うになってきており，商業的にもさまざまな特定保健用 食品や栄養機能食品, サプリメントが開発されている. 特に，エイコサペンタエン酸（EPA）やドコサヘキサ エン酸（DHA）が発揮する多彩な生理作用は広く知ら れており，一般的にも健康に良いイメージが定着してい る.

EPA D DHA は脂質（油）の一種であり，生化学的に は炭素鎖が 16 以上の長鎖脂肪酸に分類される，長鎖脂 肪酸のうち， $\omega 6$ 脂肪酸と $\omega 3$ 脂肪酸は生体内で作り出す ことのできない必須脂肪酸であり，食事などを介して捸 取する必要がある．植物性の食用油に含まれる代表的な $\omega 6$ 脂肪酸はリノール酸で，生体内でアラキドン酸へと 代謝される。一方，植物性食用油の主な $\omega 3$ 脂肪酸は aリノレン酸で, 生体内でEPAやDHAへと代謝され る.オリーブ油やココナッツ油，ごま油などさまざまな 植物性食用油が市場に出回っているが，それぞれリノー

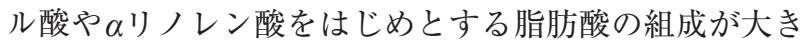
く異なる. サラ夕゙油として主に使用され，かつ多くの市 販マウス用慨に用いられている大豆油は, リノール酸を 約 50\%， $\alpha$ リノレン酸を5\%程度含む. 一方，亜麻仁油 やエゴマ油には $\alpha$ リレン酸が多く含まれていることが 知られており，その割合は大豆油の 10 倍以上の約 $60 \%$ にもなる(図1).

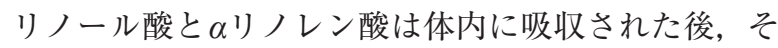
れぞれアラキドン酸や EPA/DHAに代謝される。これ らはともにシクロオキシゲナーゼやリポキシゲナーゼ, シトクロムP450などの酵素の働きにより，さまざまな 脂質メディエーターに代謝される ${ }^{(1)}$ 。アラキドン酸を由 来とする脂質メディエーターの多くが炎症の惹起にかか わることから (1)，EPAやDHAが示す抗炎症作用は，ア ラキドン酸との代謝酵素の競合阻害が主作用であると考 えられてきた(2)。しかしながら近年，質量分析技術を利 用したリピドミクス解析が発展したこともあり， EPA やDHAはアラキドン酸との競合阻害だけではなく, 積 極的に抗炎症作用を発揮する脂質メディエーターに代謝 されることで，炎症の抑制や収束にかかわっていること が判明してきた。たとえば，EPAとDHAを由来とする
レゾルビン E1 やプロテクチン D 1 は腹膜炎モデルにおい て抗炎症作用を発揮することが報告されている(3).

炎症性疾患と同様，花粉症やアトピー性皮覤炎，食物 アレルギーに代表されるアレルギー疾患は，近年患者数 が増加している疾患である。 なかでも食物アレルギーは いまだ有効な治療法が確立されていない難治性疾患であ り，アレルゲンを含む食材を摃取しないことが唯一の対 処法である。そのため患者やその家族のQuality of Life の低下が大きな問題となっている．筆者らは食用油の脂 肪酸組成に着目した研究の一つとして, 卵タンパク質で あるニワトリ卵白アルブミン（OVA）の摂取により下 痢を呈する食物アレルギーモデルを用いた解析を行い, 食物アレルギーの発症を抑制できる食用油として $\alpha$ リノ レン酸を多く含む亜麻仁油を同定した ${ }^{(4)}$ ．対照群である 大豆油を含む餌で飼育したマウスではOVAに対する $\mathrm{IgE}$ 抗体の産生とマス卜細胞の脱顆粒を伴う下痢症状が 観察されたが，亜麻仁油を含む餌で飼育したマウスでは 下痢の発症阻害が観察され，特にマス卜細胞の脱顆粒抑 制が顕著であった ${ }^{(4)}$. また亜麻仁油で飼育したマウスの 腸管組織では $\alpha$ リレン酸とその代謝物である $\mathrm{EPA}$ DHAが増加していた。このことから，食用油の脂肪酸 組成が生体の脂肪酸組成に直接的に影響を与えること, さらにそれに連動した形で食物アレルギーの発症も変化 することが判明した。

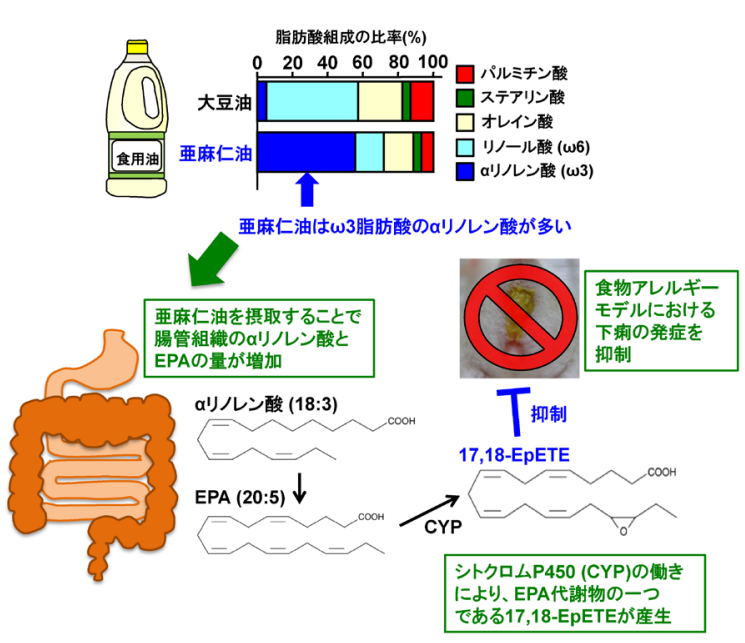

図 1 - 亜麻仁油摂取による食物アレルギ一抑制のしくみ 


\section{今日の話題}

前述のように, EPAやDHAの代謝物が示す生理活性 に注目が集まっている。筆者らも質量分析を基盤とした リピドミクス解析を行い，マウス大腸の脂質代謝物を網 羅的に測定した（理化学研究所・有田 誠博士との共同 研究)。その結果, 亜麻仁油で飼育したマウスの大腸で はEPA代謝物が増加しており，なかでもシトクロム P450によりエポキシ体となった17,18-エポキシエイコサ テトラエン酸（17,18-EpETE）の顕著な増加が認められ た．次に化学的に合成した17,18-EpETEを通常慨で飼 育したマウスに投与した際の抗アレルギー活性について 検証したところ，17,18-EpETEの投与だけでもアレル ギー性下痢の発症が抑制できることが判明した ${ }^{(4,5)}$ (図 1)。したがって，17,18-EpETEは亜麻仁油食で観察され た抗アレルギー活性を担う本体であると考えられる。

EPAから 17,18-EpETEへと変換するシトクロムP450 にはさまざまなサブファミリーや多型が存在することが 知られている。 そのため， $\alpha$ リノレン酸や EPAを摂取し ても，シトクロムP450の型によっては17,18-EpETEが 産生されない可能性がある，そのことを考えると，現 在, EPA や DHA の健康増進効果に期待した商品が多く 存在するが，今後は目的の活性をもつ代謝物そのものを 含む機能性食品やサプリメントがより有用であると期待 される。このように $\omega 3$ 脂肪酸を対象とした学術研究や その知見を活用した実用化研究は新たな時代に突入して いると言え，今後の発展が期待される.

1) M. Arita: J. Biochem., 152, 313 (2012).

2) Gruppo Italiano per lo Studio della Sopravvivenza nell'Infarto miocardico: Lancet, 354, 447 (1999).

3) J. M. Schwab, N. Chiang, M. Arita \& C. N. Serhan: Nature, 447, 869 (2007).

4) J. Kunisawa, M. Arita, T. Hayasaka, T. Harada, R. Iwamoto, R. Nagasawa, S. Shikata, T. Nagatake, H. Suzuki, E. Hashimoto et al.: Sci. Rep., 5, 9750 (2015).

5) J. Kunisawa \& H. Kiyono: Front Nutr., 3, 3 (2016).

(長竹貴広*1, 國澤 純*1,2,3,4,*1 医薬基盤・健康 - 栄養 研究所ワクチンマテリアルプロジェクト, ${ }^{2}$ 大阪大学 大学院医学系研究科・薬学研究科・歯学研究科 (連携 大学院), $* 3$ 神戸大学大学院医学研究科(連携大学院) *4 東京大学医科学研究所炎症免疫学分野/国際粘膜ワ クチン開発研究センター)

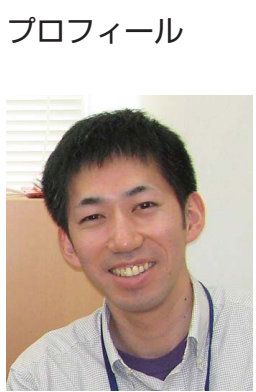

長竹 貴広 (Takahiro NAGATAKE) $<$ 略歴 $>2004$ 年明治大学農学部生命科学 科卒業 $/ 2006$ 年東京大学大学院医学系研 究科修士課程修了 $/ 2007$ 年日本学術振興 会特別研究員 (DC1) / 2010 年東京大学大 学院医学系研究科博士課程修了/同年 UHA 味覚糖株式会社 / 2011年京都大学大 学院医学研究科博士研究員 $/ 2012$ 年日本 学術振興会特別研究員 $(P D) / 2013$ 年医薬 基盤・健康・栄養研究所研究員, 現在に至 る<研究テーマと抱負 $>$ 食事性成分による 免疫システムの発達と制御の可能性につい て興味をもって研究に取り組んでいます $<$ 趣味 > 野球観戦, 観賞魚飼育, 航空観賞

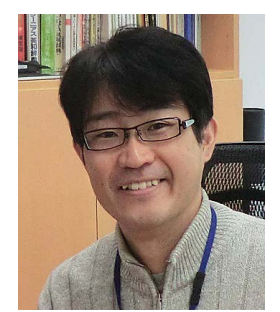

\section{國 澤 純（Jun KUNISAWA）}

$<$ 略歴>1996年大阪大学薬学部卒業/ 2000 年日本学術振興会特別研究員 (大阪 大学ならびにカリフォルニア大学バーク レー校) / 2001 年同大学大学院薬学研究科 修了 $/ 2004$ 年より東京大学医科学研究所 助手, 助教, 講師, 准教授を経て, 2013 年医薬基盤・健康・栄養研究所プロジェク トリーダー。そのほか, 大阪大学招聘教授 (医学系研究科, 薬学研究科, 歯学研究 科), 東京大学医科学研究所客員教授, 神 戸大学医学研究科客員教授を兼任 $<$ 研究 テーマと抱負＞粘膜免疫に着目したワクチ ン, 免疫創薬, 機能性食品の開発を行って います，興味のある方はアカデミア，企業 にかかわらずご連絡くださいく趣味〉読書

Copyright (C) 2017 公益社団法人日本農芸化学会 DOI: 10.1271/kagakutoseibutsu.55.11 